Supplement of Atmos. Meas. Tech., 12, 3351-3363, 2019

https://doi.org/10.5194/amt-12-3351-2019-supplement

(c) Author(s) 2019. This work is distributed under

the Creative Commons Attribution 4.0 License.

(c) (1)

\author{
Atmospheric \\ Measurement \\ Techniques
}

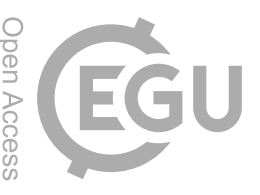

Supplement of

\title{
A novel approach to calibrating a photoacoustic absorption spectrometer using polydisperse absorbing aerosol
}

Katie Foster et al.

Correspondence to: Shane Murphy (shane.murphy@uwyo.edu)

The copyright of individual parts of the supplement might differ from the CC BY 4.0 License. 
Table S1: Noise levels of the PAS taken during filter period. Reported is the standard deviation of the mean as a function of averaging time for each of the four PAS cells.

\begin{tabular}{|l|l|l|l|}
\hline cell & 1 second data $\left(\mathrm{Mm}^{-1}\right)$ & 30 second average $\left(\mathrm{Mm}^{-1}\right)$ & 60 second average $\left(\mathrm{Mm}^{-1}\right)$ \\
\hline 405 dry & .0092 & .0039 & .0035 \\
\hline 660 dry & .0687 & .0321 & .0308 \\
\hline 405 den & .0250 & .0311 & .0225 \\
\hline 660 den & .1160 & .0196 & .0199 \\
\hline
\end{tabular}


Figure S1: Aerosol size distributions from the three different substances used for the calibration method: Aquadag (a), Regal Black (b), and Nigrosin (c). These size distributions correspond to the example calibration shown in Figures 3, 5, and S2.
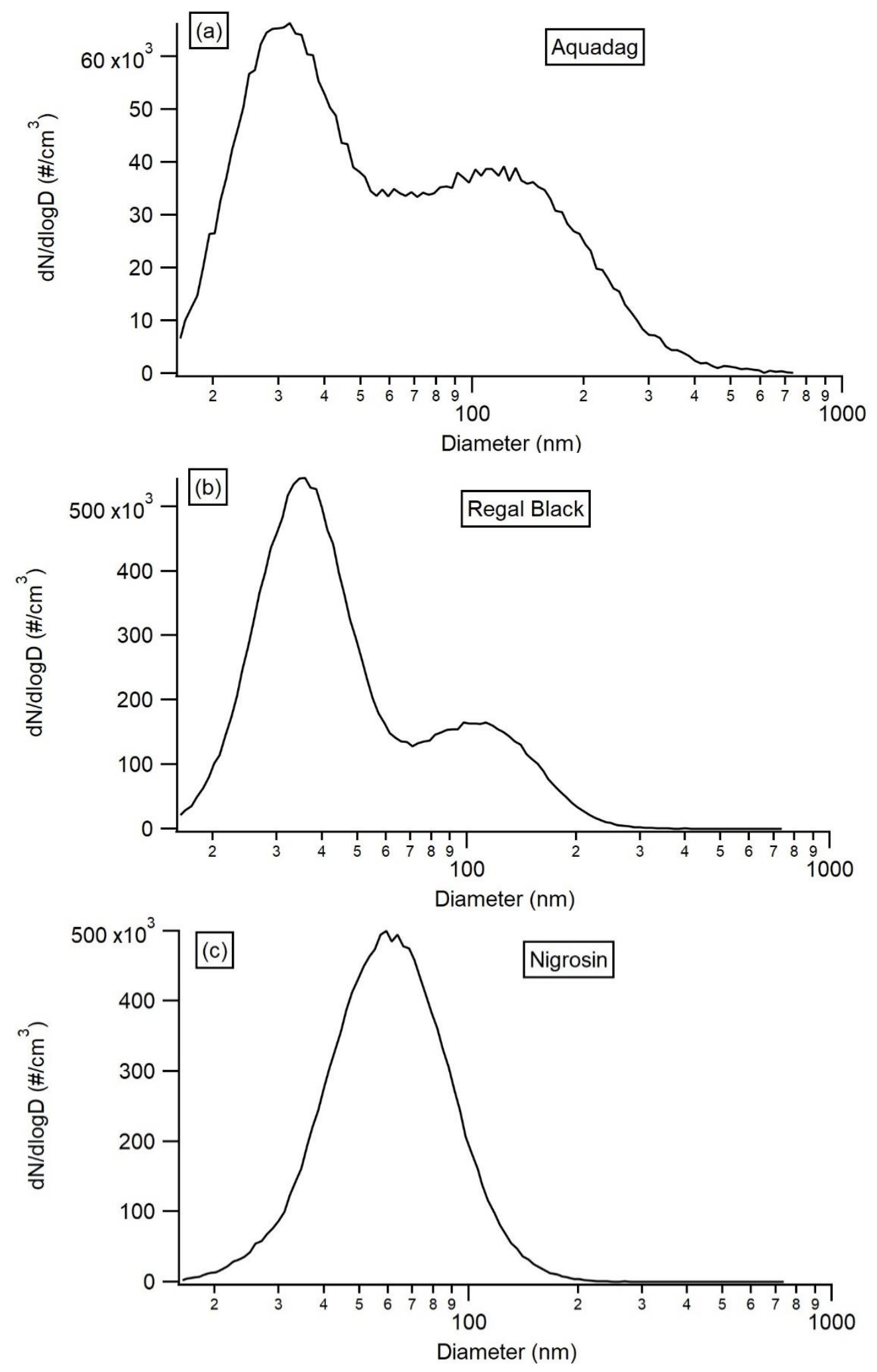
Figure S2: Single scattering albedo at $450 \mathrm{~nm}$ (blue) and $660 \mathrm{~nm}$ (red) for the three substances: Aquadag (a), Regal Black (b), and Nigrosin (c). All three of these examples correspond to the same data used in figures 3, 5, and S1. Also shown is the Extinction at $450 \mathrm{~nm}$ (black). The concentration is varied over the course of the calibration, and the lowest concentrations correspond to the highest noise in SSA calculation. For example, in the bottom panel, the first concentration of Nigrosin corresponds to only 7 $\mathrm{Mm}^{-1}$ of Extinction at $450 \mathrm{~nm}$, and 3-4 $\mathrm{Mm}^{-1}$ of scattering, resulting in a highly noise estimate of SSA.
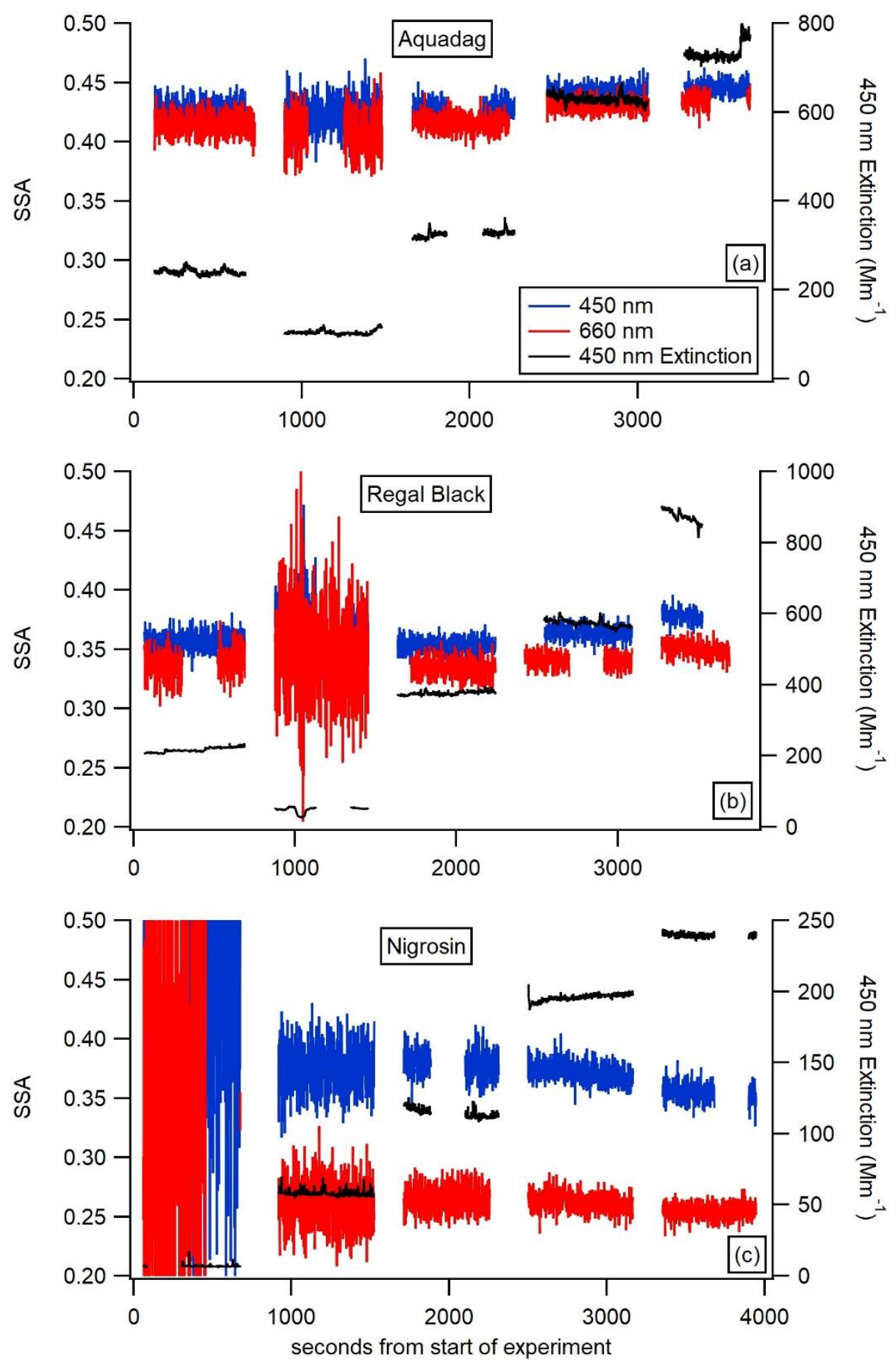